Artikel Konseptual

\title{
NILAI-NILAI KARAKTER SUNDA WIWITAN KAMPUNG NAGA SEBAGAI BAHAN PEMBELAJARAN ILMU PENGETAHUAN SOSIAL
}

\author{
Agung Wiradimadja ${ }^{1 *}$, Muhammad Arief Rakhman², Peggi Pratiwi ${ }^{2}$ \\ agung.wiradimadja.fis@um.ac.id,gento_bucho@yahoo.com,peggipra18@gmail.com \\ Prodi Pendidikan IPS, Universitas Negeri Malang ${ }^{1}$ \\ Prodi Pendidikan IPS, Universitas Pendidikan Indonesia ${ }^{2}$
}

Abstract. This article aims to describe the local cultural values possessed by the Kampung Naga community that can be used as learning materials of Social Sciences (IPS). Kampung Naga community is the people who live in Hillside of Mount Galunggung Tasikmalaya regency. They are famous for preserving the culture derived from their Karuhun who have sunda wiwitan teachings. The Karuhun leave a massage for them not to harm the nature and also to live in harmony with their fellow human beings. In order to realize their obedience to Karuhun's mandate, they apply the local wisdom of Sunda wiwitan in their daily life. The mandate of Karuhun become the rule of life of Kampung Naga community. Damaging the nature is forbidden for Kampung Naga's people, beside that in their social life they have to obey hirup sauyunan principe with another people. There are customary sanctions for custom breaker. Karuhun's mandate have been shape Kampung Naga's people to live in harmony not only with the human but also the nature. Local genius of Sunda wiwitan which contained in historical story in Kampung Naga community become important character value to study for Social Sciences

Key words: Kampung Naga Community, Sunda Wiwitan, character values, Social Science learning

\section{PENDAHULUAN}

Pendidikan karakter pada dalam dunia pendidikan akhir-akhir ini menjadi sesuatu hal yang hangat diperbincangkan. Masalah karakter pada sebagian anak-anak dan orang dewasa di Indonesia akhir-akhir ini bisa dibilang cukup memperihatinkan. Kenyataannya sekarang bangsa Indonesia telah kehilangan jari diri bangsa dengan adanya beberapa kasus kekerasan, aksi anarkis, korupsi, penggelapan pajak, pembunukan, kejahatan seksual, penjarahan, teror bom, tawuran dan lain-lain. Parahnya lagi bangsa Indonesia saat ini banyak yang senang mengedepankan kekerasan ketimbang akal pikiran dan bersabar. Hal ini menunjukan rusaknya karakter bangsa Indonesia saat ini (Jati, Suprapta, \& Wedhanto, 2014).

Beberapa kasus ini memperjelas adanya penurunan kualitas moral anak anak, antara lain portal berita dari Komisi Perlindungan Anak Indonesia (KPAI) mengabarkan seke- 
lompok anak usia SMP mengadakan perkelahian duel ala gladiator. Perkelahian ini dilakukan di lapangan Desa Gobang, Kabupaten Bogor hari Jumat (24/11). Perkelahian ala duel gladiator ini menimbulkan korban jiwa seorang anak berusia 16 tahun. Koban meninggal karena kehabisan darah setelah mendapatkan tusukan benda tajam di pinggul dan tangannya (Setyawan, 2017). Pada bulan Februari 2018 terdapat kasus pemukulan kepada Ahmad Budi Cahyono seorang guru SMA oleh siswanya di Bangkalan Madura, yang menyebabkan guru tersebut meninggal dunia pasca pemukulan. Padahal sebelumnya Ahmad Budi Cahyono sempat dilarikan ke RSU dr Soetomo Surabaya namun tetap nyawanya tidak tertolong (Gunawan, 2018; Jajeli, 2018).

Tidak hanya itu generasi muda Indonesia pun tidak terlepas dari bayang-bayang dunia hitam pornografi. Portal berita KPAI, dari 6000 anak usia SD yang dijadikan sampling dalam penelitian terkait darurat terkait pada anak usia sekolah dasar oleh Kementrian Kesehatan (Kemenkes). Hasilnya didapatkan data bahwa sebesar 91,58\% anak telah terpapar pornografi, 6,30\% diantaranya sudah mengalami kecanduan pornografi ringan, dan $0,07 \%$ lainya telah mengalami kecanduan pornografi berat (Setyawan, 2018).

Saat ini Indonesia juga sedang dilanda permasalah karakter permusuhan dalam persaudaraan sebangsa dan tanah air. Permusuhan ini berawal dari pertarungan politik pilpres tahun 2014 yang menimbulkan dampak terbaginya masyarakat Indonesia menjadi dua kubu antara paslon satu dan paslon dua. Pertarungan tersebut berlanjut lagi pada pemilihan gubernur Jakarta tahun 2017. Kedua kubu ini saling menghujat dalam dunia maya dan juga dunia nyata. Akhir-akhir ini perseteruan kedua kubu berubah menjadi perseteruan yang bermuatan SARA dan juga saling lempar informasi/berita hoax.

Beberapa kasus diatas memang tidak dipungkiri merupakan imbas negatif dari globalisasi yang mendorong kemajuan teknologi. Terutama kemajuan teknologi informasi, sehingga semua orang saat ini dapat bebas mengakses berbagai informasi yang baik maupun yang buruk. Kondisi ini diperburuk dengan lemahnya filter yang ada pada diri masyarakat memicu pembentukan karakter yang kurang baik yang bertolak belakang dengan kebudayaan bangsa Indonesia seperti penggunaan narkoba, materialisme, sikap hedonisme, konsumerisme, individualisme, radikalisme, dan primordialisme. Hal ini menjadi tanda turunnya rasa nasionalisme bangsa dan indikator merosotnya karakter bangsa. Kemerosotan nasionalisme dan karakter bangsa bisa disebabkan dari kekeliruan dalam mempelajari sejarah bangsa. Semua komponen sepakat bahwa untuk membangun nasionalisme dan karakter masyarakat menjadi prioritas utama (Setiawan, 2013).

Pemerintah Indonesia pada masa reformasi merumuskan pendidikan karakter sebagai misi pertama dari delapan misi dengan tujuan untuk mewujudkan visi pembangunan nasional. Sebagaimana tercantum dalam Rencana Pembangunan Jangka Panjang Nasional (RPJPN) Tahun 2005-2025 (Kemko Kesejahteraan Rakyat, 2010). Arah, JPSI, Vol. 1, No., 1, 2018 
tahapan dan prioritas pembangunan jangka panjang tahun 2005-2025 pada Undangundang RI No 17 tahun 2017 tentang rencana pembangunan jangka panjang nasional mengamatkan kepada:

"Terwujudnya karakter bangsa yang tangguh, kompetitif, berakhlak mulia, dan bermoral berdasarkan falsafah Pancasila, yang dicirikan dengan watak dan perilaku manusia dan masyarakat Indonesia yang beragam, beriman dan bertakwa kepada Tuhan Yang Maha Esa, berbudi luhur, bertoleran, bergotong-royong, berjiwa patriotik, berkembang dinamis, dan berorientasi iptek" (Sekretariat Negara Republik Indonesia, 2007).

Maka dari karena itu Sujud P.J. et al., (2014) menyatakan untuk menguatkan jatidiri bangsa Indonesia melalui peningkatan rasa nasionalisme dan nilai-nilai karakter dengan cara mempelajari sejarah bangsa. Hal serupa diungkapkan oleh Sayono, Nafi'ah, \& Wijaya, (2015) yang memanfaatkan dongeng Gagak Rimang sebagai cerita sejarah lokal masyarakat daerah Jawa Tengah. Dongeng ini bermanfaat dalam pengembangan kesadaran sejarah pada generasi muda sehingga mampu menumbuhkan karakter baik dalam bermasyarakat.

Jawa Timur memiliki sejarah lokal Malang dan di Jawa Tengah ada cerita Dongeng Gagak Rimang yang diangkat untuk pembelajaran nilai baik dalam pendidikan formal maupun pendidikan informal. Jawa Barat juga ada sejarah lokal bersifat kebudayaan yang dapat diangkat sebagai pendidikan nilai. Sejarah lokal yang dimaksud adalah kebudayaan/ajaran sunda wiwitan. Sunda wiwitan ini adalah kebudayaan yang dimiliki oleh orang-orang Sunda yang tinggal menetap di Jawa Barat. Sunda wiwitan sering diartikan sebagai agama kepercayaan orang-orang Sunda terdahulu. Hal itu kurang tepat, sesungguhnya sunda wiwitan juga meliputi segala aspek kehidupan masyarakat sunda seperti sistem ajaran kehidupan sosial manusia dan hubungan manusia dengan alam. Artikel ini mencoba mengangkat pembelajaran nilai karakter melalui ajaran kebudayaan sunda wiwitan sebagai materi inti dalam pembelajaran IPS. Masyarakat Jawa Barat yang masih memegang teguh ajaran sunda wiwitan diantaranya adalah masyarakat Kampung Naga, Kabupaten Tasikmalaya. Mereka mencoba untuk tetap memegang teguh ajaran ini ditengah-tengah pembangunan dan globalisasi. Mereka cenderung menolak modernisasi teknologi demi melestarikan kearifan lokal masyarakat sunda wiwitan yang sudah eksis sejak lama.

Menggali nilai-nilai karakter dari cerita sejarah lokal merupakan salah satu solusi tepat guna sebagai pembelajaran nilai-nilai sosial yang dapat diterapkan kepada peserta didik maupun mahasiswa. Tujuan pembelajaran ini tidak lain ialah membangun karakter dari para generasi muda (peserta didik dan mahasiswa) dalam pembelajaran IPS. Strategi 
pembelajarannya dapat dikemas dalam kuliah praktik lapangan (fieldtrip). Membawa peserta didik atau mahasiswa terjun langsung ke lapangan dalam pembelajaran IPS akan lebih bermakna dibanding hanya belajaran secara teoritis melalui buku saja. Melalui pembelajaran langsung di lapangan peserta didik atau mahasiswa dapat menggali informasi dari sumbernya. Mereka bisa melakukan observasi, pengukuran, dan wawancara. Kuliah berbasis praktik lapangan dapat menjadi pembelajaran IPS yang lebih powerful dan juga meaningfull. Seperti yang diungkapkan oleh Hapsari \& Widhianningrum (2014) bahwa pembelajaran praktik pengalaman langsung menunjukan peningkatan kompetensi sosial dan kepribadian mahasiswa secara signifikan terhadap kinerja mahasiswa. Hal ini menunjukan pembelajaran berbasis praktik lapangan merupakan pembelajaran yang efektif untuk mengembangkan karakter peserta didik atau mahasiswa.

\section{AJARAN SUNDA WIWITAN}

Sejarah lokal syarat akan nilai dan makna yang dapat dipelajari oleh masyarakat Jawa Barat, ialah sejarah mengenai ajaran dari sunda wiwitan. Banyak orang beranggapan bahwa sunda wiwitan ialah sebuah agama/kepercayaan terhadap karuhun atau roh nenek moyang yang dimiliki oleh orang sunda jaman dahulu. Anggapan itu terlalu sempit, sesungguhnya sunda wiwitan itu bukan hanya agama/kepercayaan semata, namun juga menyangkut tata kelola lingkungan dan juga sistem sosial. Bagaimana orang sunda wiwitan mengatur kehidupan masyarakat, dalam interaksinya dengan alam dan juga sesama manusia harus hidup berdampingan secara harmonis. Kata "wiwitan" atau kata dasarnya "kawit" artinya adalah asal mula, sedangkan sunda wiwitan ialah sunda asal atau sunda asli (Danasasmita \& Djatisunda, 1986).

Mulyadi (2017) menuturkan sunda wiwitan adalah sistem nilai ajaran kebudayaan yang hidup di tanah sunda (Jawa Barat) sejak sunda dihuni oleh manusia. Masyarakat sunda memiliki metodologi pengelolaan lingkungan, ilmu tentang sistem sosial, dan pengelolaan alam sunda terdahulu. Semuanya diterapkan dalam ilmu pengelolaan air, ilmu mengelola pesawahan, ilmu penataan lingkungan, ilmu pengelolaan pemukiman, hubungan sosial masyarakat. Masyarakat sunda wiwitan memahami bahwa alam semesta ini adalah titipan yang maha kuasa, setiap manusia tidak boleh terlalu eksploitatif. Hidup sesama manusia harus saling memberi, sayang pada sesama, tidak ada sifat serakah, bersama-sama merawat alam, merawat lingkungan. Dalam pengelolaan tanah tidak diakui milik pribadi (tidak serakah) mengambil tidak boleh terlalu banyak. Mereka menyadari alam ini milik besama dan bersifat titipan dan yang maha kuasa. Masyarakat sunda wiwitan sangat menghormati ajaran sosial. 


\section{MASYARAKAT KAMPUNG NAGA SUNDA WIWITAN}

Salah satu komunitas diantara masyarakat Jawa Barat yang masih memegang ajaran sunda wiwitan ialah komunitas masyarakat Kampung Naga. Lokasi Kampung Naga sendiri secara administratif berada di Desa Neglasari, Kecamatan Salawu, Kabupaten Tasikmalaya. Nama Kampung Naga sendiri sesungguhnya bukan diilhami dari hewan mitologi ular naga. Nama naga disini sebetulnya sebuah singkatan dari bahasa sunda "dina gawir" yang artinya berada di jurang/lereng. Memang secara lokasi Kampung Naga ini berada di kaki Gunung Galunggung, sehingga kondisi fisik tanahnya (landscape) miring (Wiradimadja, 2017).

Bentangan alam tatar sunda umumnya terdiri dari banyak bukit dan gunung. Daerah pesisir pantai di sebelah selatan tidak terlalu banyak, sehingga mendorong masyarakatnya banyak yang menjadi petani yang memanfaatkan alam dengan seksama, yaitu memanfaatkan dengan tidak merusak (Hermawan, 2014). Berdasarkan kondisi alam tatar sunda tersebut, mendidik masyarakat sunda banyak yang menjadi seorang petani ketimbang menjadi nelayan. Kehidupan masyarakat dalam koneksitasnya antara waktu dan ruang hidup (living space) membentuk pola perilaku kehidupan masyarakat dalam wujud kebudayaan (Ningrum, 2012). Masyarakat Kampung Naga ialah masyarakat gunung, semua penduduknya berprofesi sebagai petani, sama dengan masyarakat sunda terdahulu pada umumnya (Wiradimadja, 2017).

Eksistensi tradisi kebudayaan sunda wiwitan pada masyarakat Kampung Naga di tengah-tengah pembangunan dan era globalisasi ini menarik untuk dikaji dari perspektif pendidikan. Hal ini dapat kita maknai sebagai warisan budaya, yang dapat dijadikan sebagai alternatif sumber belajar IPS untuk masyarakat Jawa Barat, khususnya Tasikmalaya. Tujuan dari kajian ini adalah untuk mengetahui sejarah dan karakteristik kearifan lokal masyarakat Kampung Naga. Selain itu ialah untuk memperoleh nilai-nilai kearifan lokal yang relevan untuk pemlajaran IPS. Nilai-nilai kearifan lokal ini sebagai alternatif sumber belajar IPS yang dapat diterapkan pada kehidupan peserta didik atau mahasiswa (Qodariyah \& Armiyati, 2012).

Masyarakat Kampung Naga pantang untuk hidup bermewah-mewahan, hedonisme, boros dan sebagainya. Hal ini tercermin dari pepatah atau ungkapan kesederhanaan saeutik cukup, loba nyesa artinya sedikit cukup, banyak bersisa ungkapan lainnya menyebutkan hirup mah kudu tungkul ka jukut, tanggah ka sadap artinya hidup harus menunduk ke rumput, menengadah ke tempat menyadap. Maksud dari kedua pernyataan ini adalah kehidupan yang kita jalani harus melihat kenyataan, tidak boleh iri apa lagi dengki atas keberhasilan orang lain (Hermawan, 2014). Hal ini diterapkan dalam arsitektur rumah masyarakat Kampung Naga yang hanya terbuat dari bilik (anyaman 
bambu), dan hanya dicat menggunakan kapur saja. Selain itu di kampung ini tidak di aliri listrik, padahal jarak ke desa lainnya yang memiliki aliran listrik hanya berjarak sekitar 500 meter saja. Semua itu dimaksudkan agar semua warga Kampung Naga hidup sama. Tidak ada yang berlomba-lomba dalam kemewahan, tidak ada yang saling menyombongkan apa yang dimilikinya, dan mencegah perilaku konsumerisme. Ini adalah cara mereka mencegah perilaku boros dalam kehidupan. Supriatna, (2017) menyatakan bahwa konsumerisme adalah bentuk imperialisme baru yang ditunjukan oleh kekuatan kekuatan antara kapitalis dan konsumen. Konsumerisme adalah sebagai eksploitasi ekonomi atau hegemoni budaya.

Walaupun mereka kukuh memegang kearifan lokal dari para karuhun/kabuyutan (nenek moyang) dan tertutup terhadap perkembangan teknologi modern, namun mereka terbuka terhadap pendidikan. Anak-anak mengikuti pendidikan formal seperti masyarakat Indonesia umumnya. Mereka juga biasa naik kendaran umum (kendaraan bermotor) ketika bepergian ke tempat yang jauh, tidak seperti masyarakat Baduy Dalam. Sistem pemerintahan yang berlaku di Kampung Naga ada dua yakni dipimpin oleh kepada adat dan juga adanya RT dan RW. Hal ini didasarkan kepada pepatah leuweung lain larangeun, pamarentah lain lawaneun artinya hutan bukan untuk dirusak, pemerintah bukan untuk dilawan.

\section{KEARIFAN LOKAL MASYARAKAT KAMPUNG NAGA SEBAGAI NILAI PEN- DIDIKAN KARAKTER}

Semua elemen masyarakat setuju bahwa kearifan lokal merupakan hal yang sangat penting untuk diterapkan dalam pendidikan. Karena hal ini dapat membentuk perilaku masyarakat Indonesia menjadi berkarakter melalui pengajaran, peneladanan, pemotivasian, pembiasaan dan penegakan aturan dalam pendidikan. Baik diterapkan dalam pendidikan di lingkungan keluarga, pendidikan di sekolah maupun pendidikan di masyarakat (Hasanah, 2013). Perhatikan gambar 1 berikut: 


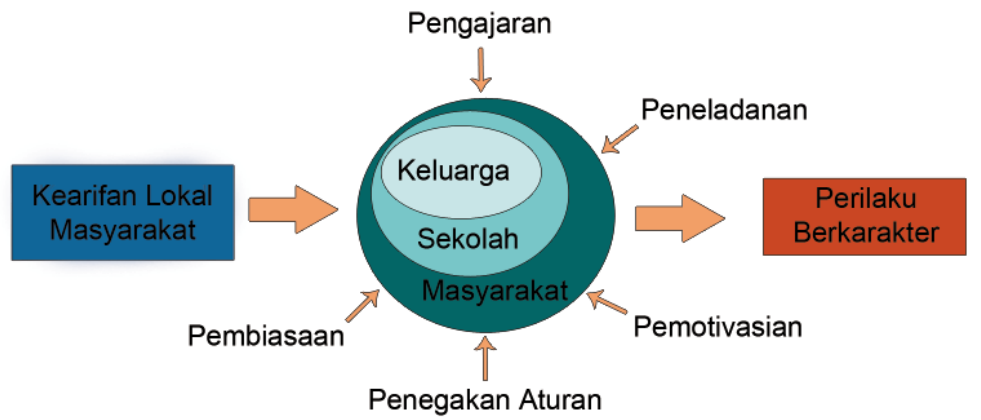

Gambar 1. Kerangka kerja pendidikan berbasis lokal (Hasanah, 2013) (dengan modifikasi oleh penulis)

Berikut adalah beberapa kearifan lokal masyarakat Kampung Naga yang dapat digali nilai-nilai karakter yang terkandung di dalamnya:

1. Konsep Pemukiman Luhur Handap

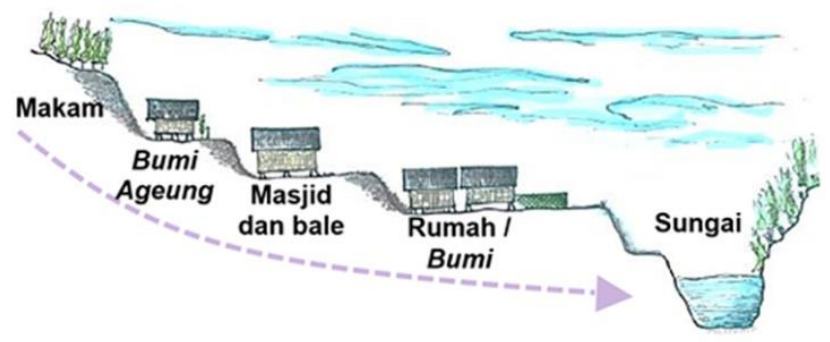

Gambar 2. Konsep pemukiman “Iuhur-handap" (atas-bawah) (Khairunnisa, 2014: 54).

Lokasi Kampung Naga ini terletak di kaki Gunung Galunggung, menyebabkan kondisi wilayahnya miring. Kondisi tanah yang miring dimanfaatkan oleh masyarakatnya menjadi konsep pemukiman luhur handap dengan sistem terasering/berundak-undak. Uniknya dalam pembangunan rumah dan pondasi terasering ini tidak menggunakan semen. Mereka hanya menumpuk batu-batu kali tanpa bahan perekat sama sekali. Kampung Naga Ini terbagi menjadi tiga bagian, yaitu: wilayah suci, wilayah bersih (pemukiman) dan wilayah kotor. Wilayah suci ialah wilayah yang dikeramatkan/disakralkan, wilayah bersih adalah tempat pemukiman warga Kampung Naga, sedangkan wilayah kotor adalah wilayah yang dimanfaatkan oleh warga Kampung Naga untuk menempatkan kandang ternak dan mengurai limbah rumah tangga. Semua limbah rumah tangga dimasukan kedalam kolam ikan termasuk aktivitas buang hajat, limbah tersebut dengan sendirinya akan diuraikan oleh organisme-organisme di dalam kolam. Sehingga air yang 
turun dari dataran tinggi tidak membawa limbah ke sungai. (Khairunnisa, 2014; Maryani \& Yani, 2014; Wiradimadja, 2017). (Perhatikan gambar 2 dan 6).

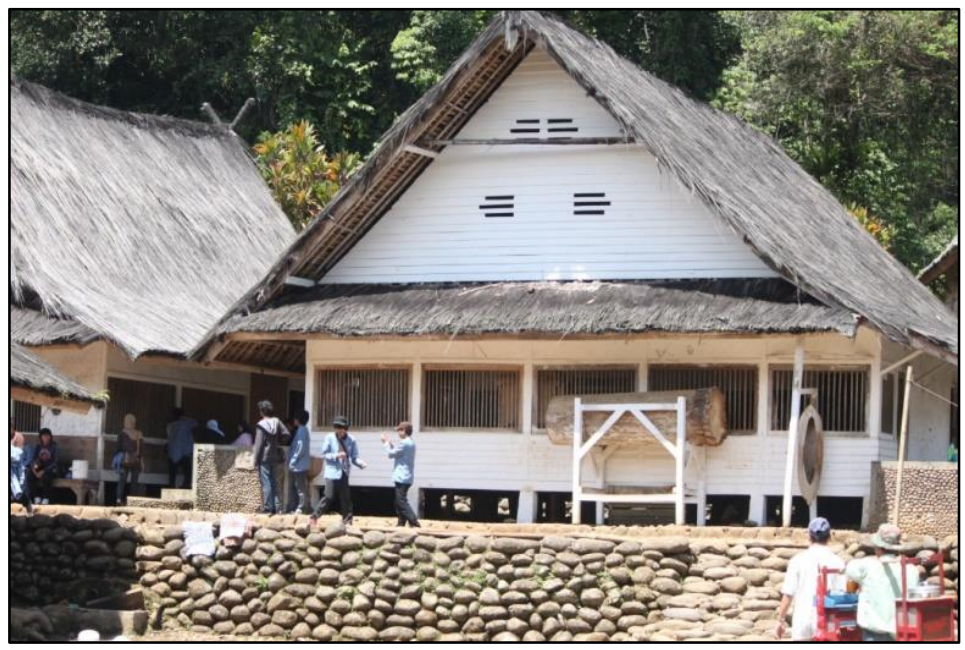

Gambar 3. Bangunan mesjid dan batu pondasi terasering Masyarakat Kampung Naga (Wiradimadja, 2017)

\section{Arsitektur/Desain Bentuk Rumah}

Bentuk rumah yang diperbolehkan untuk dibangun di kampung ini hanya bentuk rumah panggung saja mempertahankan arsitektur bangunan rumah adat sunda. Material yang digunakan pun hanya material alami seperti dinding dari bilik bambu dan papan kayu yang dicat putih menggunakan kapur, atap terbuat dari injuk (ijuk), dan bagian bawah ditopang oleh batu untuk menghindari kayunya membusuk/keropos karena air hujan dan juga menghindari rayap. Semua kerangka rumah dipasang tanpa menggunakan paku besi, mereka menggunakan paku yang terbuat dari bambu (Maryani \& Yani, 2014; Sukawi, 2010; Wiradimadja, 2017). (Perhatikan gambar 3 dan 4).

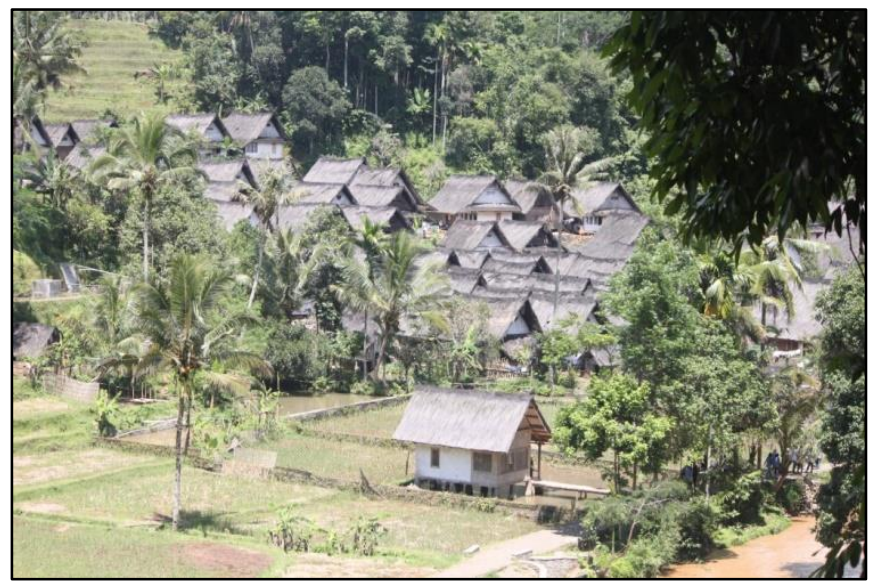

Gambar 4. Rumah-rumah Masyarakat Kampung Naga (dokumentasi pribadi, 2010) 


\section{Sistem Mata Pencaharian}

Sudah disinggung sebelumnya di atas bahwa masyarakat Kampung Naga ialah masyarakat menetap di kaki Gunung Galunggung. Mereka didik oleh alam untuk mengolah tanah menjadi petani. Segala aktifitas pertanian dilakukan menggunakan peralatan tradisional. Maka hasil pertaniannya pun hanya digunakan untuk kebutuhan pangan pribadi saja, bukan untuk di jual ke pasar. Padi hasil panen dijemur terlebih dahulu sebelum disimpan pada leuit (bangunan tempat menyimpan hasil panen padi). Diantara mereka ada juga yang beternak ayam, kambing, sapi dan juga ikan. Sebagian warga ketika sedang tidak melakukan aktivitas pertanian, mereka membuat kerajinan baik itu souvenir maupun peralatan dapur yang terbuat dari bambu dan kayu (seperti bushcraft) dan peralatan berkebun (Wiradimadja, 2017). (Perhatikan gambar 5).

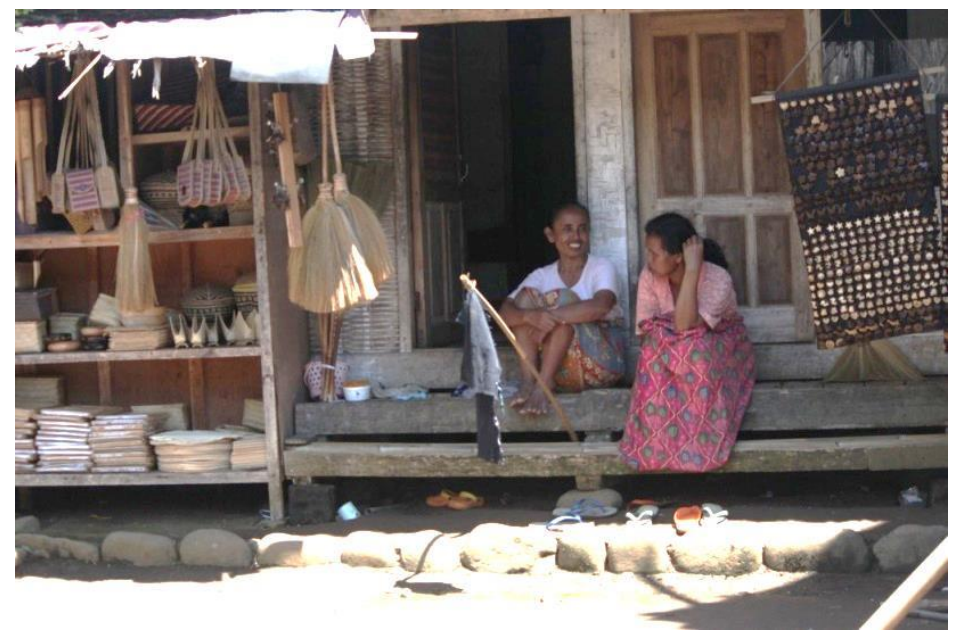

Gambar 5. Souvernir dan peralatan yang dijual oleh penduduk Kampung Naga (dokumentasi pribadi, 2010)

\section{Sistem Peralatan}

Semua peralatan yang digunakan, mulai dari peralatan rumah tangga hingga peralatan pertanian menggunakan peralatan tradisional. Penggunaan peralatan modern tidak ada yang diperbolehkan ditempat ini, walaupun sesungguhnya mereka mampu membeli alat tersebut. Contohnya, ketika mau memulai menanam padi mereka membajak sawah menggunakan bajak sawah tradisional yang ditarik hewan ternak seperti sapi atau kerbau. Peralatan pembersih diri pun ketika mandi tidak diperbolehkan menggunakan produk-produk berbahan kimia. Mereka menggunakan "taneuh porang" (tanah liat/lempung) sebagai pengganti sabun, rumput orang-aring, lidah buaya atau jeruk nipis yang ditumbuk untuk pengganti shampo, "eurih jeung lebu" (abu gosok/arang JPSI, Vol. 1, No., 1, 2018 
(charcoal) dan daun ilalang) untuk menyikat gigi. Uniknya kebiasaan ini sudah diadopsi sejak lama oleh masyarakat sunda (Wiradimadja, 2017).

5. Konservasi alam

Adanya leuweung larangan (hutan keramat/hutan larangan) membuktikan bahwa masyarakat Kampung Naga juga melakukan konservasi alam. Wilayah ini adalah wilayah yang sakral. Anggita masyarakat tidak ada yang berani memasuki wilayah tersebut karena sangat menghargai pikukuh (aturan adat) Wilayah yang dikeramatkan oleh masyarakat Kampung Naga adalah wilayah yang ada di sekitar makam keramat dan hutan di seberang Sungai Ciwulan (lihat gambar 2 dan 6). Tidak ada yang boleh mengambil hasil hutan dari hutan keramat. Untuk masuk kesana pun ada hari-hari tertentu yang diperbolehkan. Pamali (tabu/terlarang) bagi siapapun untuk memasuki daerah tersebut pada hari-hari terlarang (Maryani \& Yani, 2014; Wiradimadja, 2017).

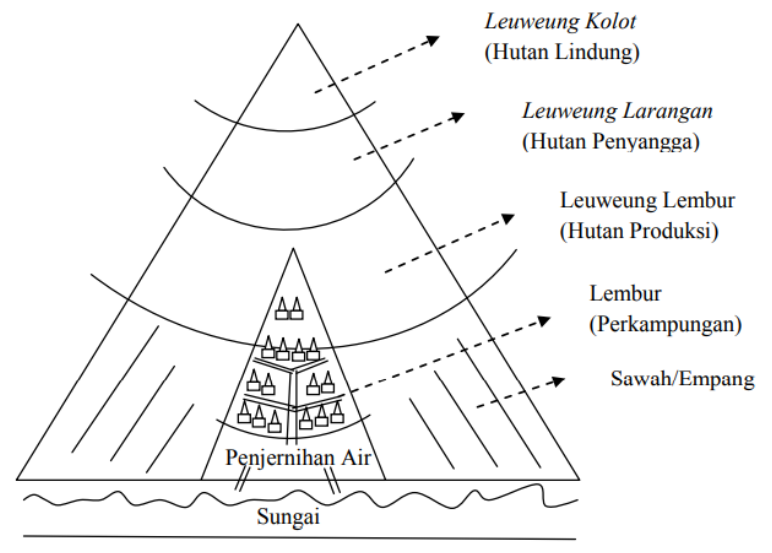

Gambar 6. Skema Zonasi/Tata ruang penggunaan lahan mikro (Maryani \& Yani, 2014)

\section{PENANAMAN NILAI-NILAI KARAKTER MASYARAKAT KAMPUNG NAGA DALAM PENDIDIKAN FORMAL DI KEHIDUPAN MASYARAKAT MODERN}

Sunda wiwitan terdahulu memang memiliki konsep kepercayaan kepada roh karuhun (nenek moyang) yang dianggap menjadi kabuyutan (sesuatu yang dijunjung/dihormati). Masyarakat Kampung Naga saat ini telah memeluk Agama Islam, namun dalam beberapa kesempatan mereka masih melakukan ritual-ritual peninggalan dari para karuhun. Sunda wiwitan dan Islam memiliki sudut pandang (perenialisme) yang serupa tentang alam, yakni tidak boleh merusak alam. Perenialisme melihat pendidikan adalah proses penting dalam penanamam nilai budaya kepada peserta didik. Nilai-nilai karakter dari kebudayaan masyarakat penting untuk ditransfromasikan melalui pendidikan, sehingga dapat diketahui, dihayati dan diterima peserta didik. Perenialisme melihat bahwa 
sejarah adalah mata rantai kehidupan manusia yang tidak boleh dilupakan. Sejarah merupakan bagian penting dari perjalanan kehidupan manusia manusia yang dapat berpengaruh terhadap kejadian masa sekarang dan masa yang akan datang. Nilai-nilai karakter dari kebudayaan yang lahir pada masa lampau merupakan hal berharga untuk diwariskan kepada generasi muda (Qodariyah \& Armiyati, 2012).

embahasan tentang relasi antara kebudayaan dengan ekologi tidak dapat dilepaskan dari adanya kearifan local yang membangun kebudayaan tersebut. Akhir-akhir ini kearifan lokal menjadi topik yang masuk kedalam materi ajar dalam dunia pendidikan. Kearifan lokal masyarakat Kampung Naga pun sangat relevan untuk dijadikan materi ajar dalam pelajaran IPS di sekolah formal di Jawa Barat.

Misalnya saja pembagian wilayah Kampung Naga menjadi tiga wilayah penggunaan peralatan tradisional, dan juga bahan-bahan alami untuk mandi, hal tersebut dimaksudkan untuk menjaga kelestarian alam sekitar kampung. Mereka percaya bahwa produk-produk yang mengendung bahan kimia dapat merusak alam. Katakan saja sungaisungai yang menghitam yang ada di kota-kota besar. Bahkan sekarang beberapa produsen produk kosmetik melirik kearifan lokal masyarakat sunda terdahulu. Beberapa produsen membuat pasta gigi, sabun muka berbahan arang (charcoal), pelembab kulit berbahan tanah liat/lempung, shampo berbahan dasar lidah buaya atau orang-aring dan sebagainya. Penggunaan arsitektur bangunan adat sunda (rumah panggung) menyesuaikan dengan lokasi mereka yang berada di kaki gunung berapi. Sewaktu-waktu ketika terjadi gempa bumi rumah itu akan mengikuti goyangan gempa dengan lentur, karena terbuat dari kayu dan bambu. Namun goncangan gempa tidak akan membuat bangunan rumah tersebut roboh (Maryani \& Yani, 2014; Sukawi, 2010; Wiradimadja, 2017).

Sistem terasering batu tumpuk membuat air hujan yang turun meresap kedalam tanah dan memungkinkan-mengalir melalui celah-celah batu, sehingga tidak ada tanah yang jenuh karena terlalu banyak menampung air yang bisa mengakibatkan longsor. Penggunaan warna cat rumah satu warna dan tidak adanya aliran listrik dimaksudkan agar semua masyarakat sama tidak saling sombong atas apa yang dimiliki. Apalagi masyarakat sunda memiliki pikukuh (aturan) "silih asih, silih asah, silih asuh sebagai kearifan budaya yang mengandung nilai keharmonisan dalam hidup sesama manusia (Saleh, Soejadi, \& Lasiyo, 2013; Wiradimadja, 2017).

Kearifan lokal masyarakat Kampung Naga ini dapat bermanfaat sebagai materi mitigasi bencana alam dan juga pembelajaran nilai-nilai sosial dalam pembelajaran IPS di sekolah. Sejalan dengan apa yang pernah diungkapkan oleh (As'ari \& Hendriawan, 2016; Maryani \& Yani, 2014) dalam penelitiannya yang menyimpulkan bahwa kearifan lokal dari kebudayaan sunda sangat signifikan dalam mitigasi bencana. Selain itu penerapan pembelajaran kearifan lokal dalam pembelajaran di sekolah formal bermanfaat untuk 
mengenalkan dan melestarikan kebudayaan lokal pada generasi muda yang sudah mulai tergerus dengan kemajuan arus globalisasi.

\section{SIMPULAN}

Ajaran sunda wiwitan pada masyarakat Kampung Naga adalah warisan dari kebudayaan masyarakat sunda terdahulu yang sangat berharga. Hal ini tercermin dalam berbagai kebudayaan dan kearifan lokal masyarakat sunda yang dapat digunakan untuk membantu masyarakat modern, dalam mengali nilai-nilai sosial, melestarikan alam dan juga sebagai mitigasi dari bencana alam. Hal tersebut menggambarkan nilai karakter peduli kepada sesama manusia dan sikap peduli lingkungan. Selain mempelajari kebudayaan dan teknologi-teknologi tradisional dari kearifan lokal masyarakat sunda, kegiatan belajar ini sekaligus mengenalkan dan melestarikan kebudayaan sunda kepada generasi muda. Kesimpulannya kebudayaan dan kearifan lokal masyarakat sunda wiwitan yang dimiliki oleh masyarakat Kampung Naga, sangat relevan untuk menjadi materi pelajaran IPS, dan sangat memungkinkan untuk diangkat menjadi materi pembelajaran IPS di sekolah-sekolah formal di Jawa Barat.

\section{RUJUKAN}

As'ari, R., \& Hendriawan, N. (2016). Kajian Nilai Kearifan Lokal Masyarakat Adat Kampung Naga Dalam Pengelolaan Lingkungan Berbasis Mitigasi Bencana. Prosiding Seminar Nasional Geografi UMS 2016 "Upaya Pengurangan Risiko Bencana Terkait Perubahan Iklim, 472-486.

Danasasmita, S., \& Djatisunda, A. (1986). Kehidupan Masyarakat Kanekes. Jakarta: Direktoral Jendral Kebudayaan, Departemen Pendidikan dan Kebudayaan.

Gunawan, H. (2018, February 3). Kronologis Pemukulan Guru Oleh Siswa, Sesampai di Rumah Ahmad Budi Cahyono Pusing Lalu Tewas. Tribunnews.Com. Retrieved from http://www.tribunnews.com/regional/2018/02/03/kronologis-pemukulan-guru-oleh-siswa-sesampai-di-rumah-ahmad-budi-cahyono-pusinglalu-tewas?page $=3$

Hapsari, P., \& Widhianningrum, P. (2014). Pengaruh Praktik Pengalaman Lapangan Terhadap Kinerja Mahasiswa Calon Guru. Journal Of Accounting and Business Education, 2(1), 1-5.

Hasanah, A. (2013). Model Penanaman Nilai-nilai Karakter Berbasis Kearifan Lokal (Studi Kasus Pada Masyarakat Adat Kampung Naga, Tasikmalaya) (Laporan Penelitian). Bandung: UIN Sunan Gunung Djati. Retrieved from 
http://digilib.uinsgd.ac.id/4122/1/Aan_Hasanah_Penelitian_Model_Penanaman_Nilai2_Karakter_Berbasis_Kearifan_Lokal.pdf

Hermawan, I. (2014). Bangunan Tradisional Kampung Naga: Bentuk Kearifan Warisan Leluhur Masyarakat Sunda. SOSIO DIDAKTIKA: Social Science Education Journal, 1(2). https://doi.org/10.15408/sd.v1i2.1256

Jati, S.S.P. , Suprapta, B., \& Wedhanto, S. (2014). Ekplorasi Nilai-Nilai Pendidikan Karakter Bangsa Dari Sejarah Lokal Malang Mulai Zaman Prasejarah Sampai Mama Hindi-Budha Abad XI. Jurnal Sejarah Dan Budaya, 8(1), 83-95. https://doi.org/DOI: http://dx.doi.org/10.17977/sb.v8i1.4757

Jajeli, R. (2018, February 2). Guru SMA di Sampang, Madura Tewas Diduga Karena Dianiaya Siswa. Detik.Com. Retrieved from https://news.detik.com/berita/d3845896/guru-sma-di-sampang-madura-tewas-diduga-karena-dianiayasiswa

Kemko Kesejahteraan Rakyat. (2010). Kebijakan Nasional Pembangunan Karakter bangsa. Jakarta: Kemko Kesejahteraan Rakyat. Retrieved from http://www.new-indonesia.org/beranda/images/upload/dok/kurikulum/kebijakan-nasionalpembangunan-karakter-bangsa-2010-2025.pdf

Khairunnisa, M. (2014). Kosmologi Ruang Aadat sebagai Identitas Pemukiman Kampung Naga, Tasikmalaya-Jawa Barat. Teknik, 35(1). https://doi.org/10.14710/teknik.v35i1.7040

Maryani, E., \& Yani, A. (2014). Kearifan Lokal Masyarakat Sunda Dalam Memitigasi Bencana dan Aplikasi Sebagai Sumber Pembelajaran IPS Berbasis Nilai. Jurnal Penelitian Pendidikan, 14(2), 114-125.

Mulyadi, D. (2017). Bukan Ajaran Sesat, Sunda Wiwitan adalah IImu Mengelola Alam. iNews Talkshow \& Magazine. Retrieved from iNews Talkshow \& Magazine: https://www.youtube.com/watch?v=ENQkl3gOhul

Ningrum, E. (2012). Dinamika Masyarakat Tradisional Kampung Naga di Kabupaten Tasikmalaya. MIMBAR, Jurnal Sosial Dan Pembangunan, 28(1), 47. https://doi.org/10.29313/mimbar.v28i1.338

Qodariyah, L., \& Armiyati, L. (2012). Nilai-Nilai Kearifan Lokal Masyarakat Adat Kampung Naga Sebagai Alternatif Sumber Belajar. Socia Jurnal IImu-IImu Sosial, 10(1), 47-54. http://dx.doi.org/10.21831/socia.v10i1.5338

Saleh, F., Soejadi, S., \& Lasiyo, L. (2013). Makna "SILAS" Menurut Kearifan Budaya Sunda Perspektif Filsafat Nilai: Relevansinya Bagi Pemberdayaan Masyarakat Miskin. Sosiohumaniora: Journal of Social Science and Humanities, 15(2). 
Sayono, J., Nafi'ah, U., \& Wijaya, D. N. (2015). Nilai-nilai Pendidikan Karakter dalam Dongeng Gagak Rimang. Jurnal Sejarah Dan Budaya, 9(2), 236-255. https://doi.org/DOI: http://dx.doi.org/10.17977/sb.v9i2.5015

Sekretariat Negara Republik Indonesia. (2007, February 5). Undang-undang Republik Indonesia Nomor 17 Tahun 2007 Tentang Rencana Ppembangunan Jangka Panjang Nasional Tahun 2005 - 2025. Jakarta: Sekretariat Negara RI.

Setiawan, D. (2013). Peran Pendidikan Karakter dalam Mengembangkan Kecerdasan Moral. Jurnal Pendidikan Karakter, 3(1), 53-63. http://dx.doi.org/10.21831/jpk.v0i1.1287

Setyawan, D. (2017, November 28). Tarung ala Gladiator Kembali Tewaskan Satu Siswa SMP di Bogor, KPAI: Polisi Sebut sebagai Adu Kebal. Komisi Perlindungan Anak Indonesia. Retrieved from http://www.kpai.go.id/artikel/tarung-alagladiator-kembali-tewaskan-satu-siswa-smp-di-bogor-kpai-polisi-sebut-sebagai-adu-kebal/

Setyawan, D. (2018, March 31). KPAI: Darurat Pornografi pada Anak SD, Orangtua Harus Tingkatkan Pengawasan. Komisi Perlindungan Anak Indonesia. Retrieved from http://www.kpai.go.id/berita/kpai-darurat-pornografi-pada-anak-sdorangtua-harus-tingkatkan-pengawasan/

Sukawi, S. (2010). Bambu: Alternatif Bahan Bangunan di Daerah Rawan Gempa, 10(1). Retrieved from http://jurnal.upi.edu/teras/view/254/bambu:-alternatif-bahan-bangunan-di-daerah-rawan-gempa.html

Supriatna, N. (2017). Confronting Consumerism as a New Imperialism: Students' Narratives in the Indonesian History Learning. The Journal of Social Studies Education, 6(1), 1-12.

Wiradimadja, A. (2017). Kearifan Lokal Masyarakat Kampung Naga Sebagai Wujud Menjaga Alam dan Konservasi Budaya Sunda. Disampaikan Pada Seminar Nasional Kontekstualisasi Pendidikan Transformatif Atas Masyarakat Adat, Jurusan Sosiologi Universitas Negeri Malang, Tanggal 22 Agustus 2017, Aula Utama Ki Hajar Dewantoro FIS-UM. 